\title{
Toxicity Study of Heavy Metals Pollutants and Physico-Chemical Characterization of Effluents Collected from Different Paint Industries in Addis Ababa, Ethiopia
}

\author{
Tesfalem Belay Woldeamanuale* and Abdrie Seid Hassen \\ Department of Environmental pollution, Ethiopia Environment and Forest Research Institute, Africa
}

Submission: October 27, 2017; Published: November 16, 2017

*Corresponding author: Tesfalem Belay Woldeamanuale, Department of Environmental pollution, Ethiopia Environment and Forest Research Institute, Africa, Email: tesbel23@gmail.com

\begin{abstract}
The present research work deals with the assessment of pollution due to toxic heavy metals in the industrial effluents collected from paint industries. The study reveals that paints industries are some of the major industries contributing to the heavy metal pollutants in the surrounding aquatic environment. It was observed that paint manufacturing industries are the major contributors of toxic $\mathrm{Cu}, \mathrm{Cd}$ and $\mathrm{Pb}$ amounting to 189.16 , 69.22 and $53.4 \mathrm{mg} / \mathrm{L}$ from Bright and Rainbow paint industries respectively. It was also observed that major contribution of $\mathrm{Ag}(28.06 \mathrm{mg} / \mathrm{L})$ was from Bright paint manufacturing units, while maximum $\mathrm{Cr}$ concentration of $9.32 \mathrm{mg} / \mathrm{L}$ was found in effluent samples released from Nifas silk paint industry. The overall results point out high concentration of toxic heavy metals in the effluent samples collected from different paint industries. The results obtained from the physicochemical analysis of all the samples of effluent indicated high alkaline pH, BOD, COD TSS and P04. These industrial effluents will pollute the nearby water bodies affecting the growth of vegetation and aquatic life. These toxic heavy metals when released in aquatic environment will enter the food chain through bio-magnification causing various health problems in humans. The results of the present investigation point out the need to implement common objectives, compatible policies and programs for improvement in the industrial waste water treatment methods..
\end{abstract}

Keywords: Industrial Effluent; Industrial Pollution; Toxic Heavy Metals; Quantification; AAS; Health Hazards; Water Pollution

Abbreviations: COD: Chemical Oxygen Demand, BOD5: Biological Oxygen Demand; SS: Suspended solids

\section{Introduction}

Paint industry is one of the industry the causes of water pollution. Wastewater is generated primarily due to cleaning operations of mixers, reactors, blenders, packing machines and floors [1]. The effluent has high organic and inorganic toxic pollutants. The discharge of such wastewater with high pollutants into the environment damage the quality of water bodies and also affect food chain hence it is essential to treat the wastewater before its disposal [2]. Paint is generally considered as a mixture of pigment, binder, solvent and additives, and the type and proportion of each component in the mixture characterize the properties of a particular paint. The components of paint also determine the characteristics of the waste generated in its manufacture and use [3]. Water-based paints generally consist of organic and inorganic pigments and dyestuffs, extenders, cellulosic and non-cellulosic thickeners, latexes, emulsifying agents, anti-foaming agents, preservatives, solvents and coalescing agents [4]. The paint wastewaters are characterized by including substantial organic matter, high salinity, sulfate rich and high suspended solid [5]. Untreated or allegedly treated paint industrial effluents contains variable amounts of heavy metals such as arsenic, lead, nickel, cadmium, copper, mercury, zinc and chromium[6,7], which have the potential to contaminate crops growing under such irrigation. These heavy metals have a marked effect on the aquatic flora and fauna which through bio-magnification enter the food chain and ultimately affect the human beings as well. Heavy metal pollution is an ever increasing problem of our oceans, lakes and rivers. 
Incidence of heavy metal accumulation in fish, oysters, sediments and other components of aquatic ecosystems has been reported globally [8-18]. These toxic heavy metals entering in aquatic environment are adsorbed onto particulate matter, although they can form free metal ions and soluble complexes that are available for uptake by biological organisms. The metals associated with particulate material are also available for biological uptake [19], and are deposited in estuarine sediments [20]. Once deposited, binding by sulfides and/or iron hydroxides immobilizes trace metals until a change in redox or $\mathrm{pH}$ occurs $[21,22]$. Thus, surfical sediments, particularly the fine fraction, accumulate trace metals and provide a means for evaluating the long term accumulation of contaminants [23,24]. The present day by day increasing tremendous industrial pollution [8-18] has prompted us to carry the systematic and detail study of pollution due to toxic heavy metals in waste water samples collected from Addis Ababa paint Industries which is considered as one of the fastest developing industrial belt, Ethiopia. The aim of the work was evaluating the heavy metal contents and Physico-chemical properties of paint waste waters.

\section{Materials and Methods}

The study was conducted in Addis Ababa at five paint manufacturing industries. Namely Nifas Silk, Zemilli, Cadisco, Bright and Rain Bow paint factories. This Paints Factory is an Ethiopian manufacturer of different kinds of Paint products which were used widely in constructions industries and transport sectors. The industrial waste water effluent samples were collected randomly twice in a year from different paintingindustries like Nifas Silk, Zemilli, Cadisco, Bright and Rain Bow paint industries, Addis Ababa Industrial belt. For each of paint industry three representative units was selected. The sample were collected by $2 \mathrm{~L}$ polyethene bottle, the bottles were thoroughly cleaned with hydrochloric acid, washed with tape water to render free of acid, washed with distilled water twice, again rinsed with the water sample to be collected and then filled up the bottle with the sample leaving only a small air gap at the top. Water samples $(500 \mathrm{~mL})$ were filtered using Whitman No. $41(0.45 \mu \mathrm{m}$ pore size) filter paper for estimation of dissolved metal content. Filtrate $(500 \mathrm{~mL})$ sample was preserved with the $1 \mathrm{ml}$ conc. HNO3 to prevent the precipitation of metals and stored at $4 \mathrm{oC}$ until use. Samples were kept in a portable cooler containing ice, to maintain an inert temperature condition for the effluent and were transported to the laboratory for analysis. The samples were concentrated to tenfold on a water bath and subjected to nitric acid digestion using the microwave-assisted technique $[25,26]$.

\section{A. Physical and Chemical Analyses of Waste Water}

\section{Samples}

All the physical and chemical analyses were determined by the procedures recommended in the Standard methods for the examination of Water and Wastewater [27]. PH, Chemical Oxygen Demand (COD), Biological Oxygen Demand (BOD5), reactive phosphate and Suspended solids (SS) were detected.

\section{B. Heavy Metal Analysis}

The analysis for the majority of the trace metals like chromium (Cr), cadmium (Cd), copper ( $\mathrm{Cu}$ ), lead (Pb) and Silver (Ag) was done by Atomic Absorption Spectrophotometer. The calibration curves were prepared separately for all the metals by running different concentrations of standard solutions. A reagent blank sample was analyzed and subtracted from the samples to correct for reagent impurities and other sources of errors from the environment. Average values of three replicates were taken for each determination.

\section{Result and Discussion}

Table 1: Heavy Metal Content and Physico Chemical properties of Effluent Samples Collected from different paint Industries.

\begin{tabular}{|c|c|c|c|c|c|}
\hline \multirow{2}{*}{ Parameter } & \multicolumn{5}{|c|}{ Name of painting Industries } \\
\hline & Nifas Silk & Zemillic & Cadisco & Bright & Rainbow \\
\hline $\mathrm{PH}$ & 6.72 & 7.16 & 6.77 & 6.48 & 7.7 \\
\hline SS & 6912.5 & 9525 & 1965 & 8862.5 & 22528 \\
\hline $\mathrm{PO}-24$ & 15.37 & 41.8 & 2.265 & 44.5 & 65.375 \\
\hline BOD & 350 & 246 & 47 & 360 & 600 \\
\hline COD & 1949 & 3524 & 425 & 2887.2 & 7662.5 \\
\hline $\mathrm{Cr}$ & 9.32 & 8.25 & 1.5 & 5.28 & 2.95 \\
\hline $\mathrm{Pb}$ & 8.33 & 24.84 & 0.68 & 18.73 & 53.4 \\
\hline $\mathrm{Cd}$ & 7.813 & 2.47 & 1.58 & 16.82 & 69.22 \\
\hline $\mathrm{Cu}$ & 2.24 & 9.22 & 2.09 & 189.16 & 22.47 \\
\hline $\mathrm{Ag}$ & 5.69 & 15.23 & 6.08 & 28.06 & 14.72 \\
\hline
\end{tabular}

${ }^{*}$ All parameters are in $\mathrm{mg} / \mathrm{l}$ except $\mathrm{PH}^{*}$ 


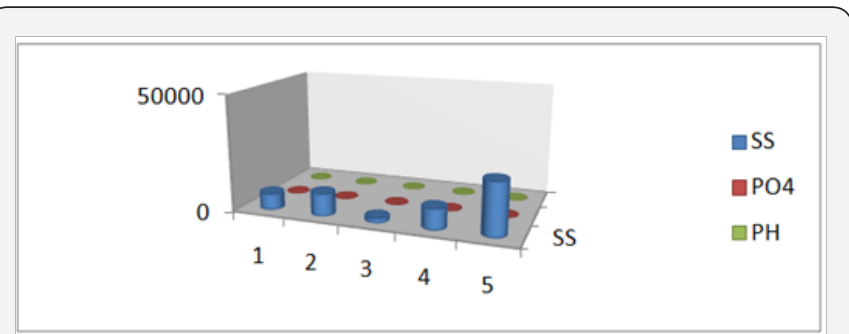

Figure 1: $B O D$ and $C O D$ content in the waste water effluents released from different paint industries of Addis Ababa, Ethiopia.

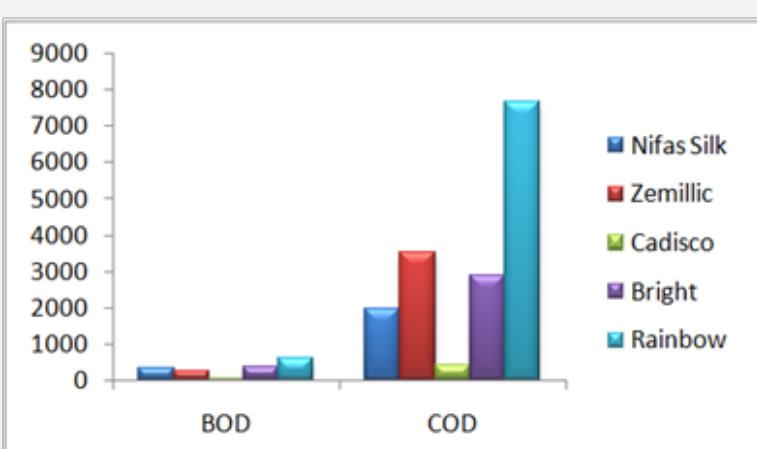

Figure 2: $B O D$ and $C O D$ content in the waste water effluents released from different paint industries of Addis Ababa, Ethiopia.

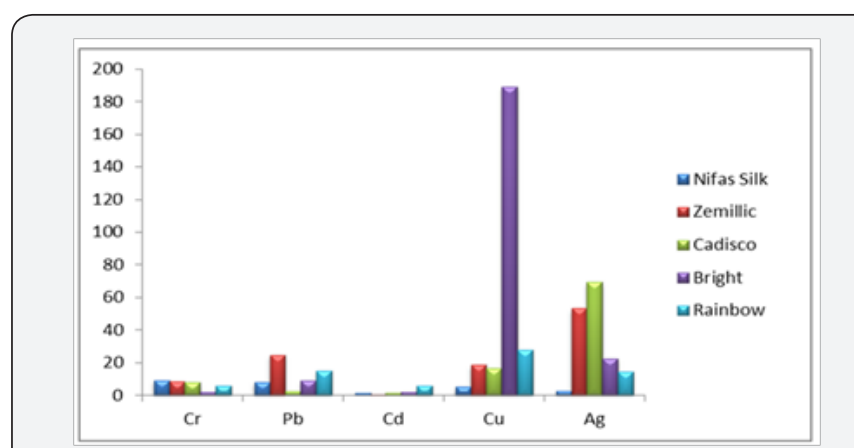

Figure 3: Heavy metal content in the waste water effluents released from different paint industries of Add is Ababa, Ethiopia

The experimental data on heavy metal content and physico chemical properties of waste water effluent samples collected from different paint industries of Addis Ababa industrial City of Ethiopia for the assessment were presented in Table 1. The heavy metal concentration and physico Chemical properties in $\mathrm{mg} / \mathrm{L}$ for different paint industries are graphically represented in Figures 1-3 and Table 1. Heavy Metal Content and Physico Chemical properties of Effluent Samples Collected from different paint Industries. The results of the study revealed that the $\mathrm{pH}$ of untreated paint effluent has a minimum range of 6.72 and a maximum range of 7.77 this indicate the alkaline nature of the paint effluent.PH is a measure of the acidity or alkalinity of water and one of the stable measurements. $\mathrm{PH}$ is a simple parameter but it is extremely important, since most of the chemical reactions in aquatic environment are controlled by any change in its value. Anything either highly acidic or alkaline would kill marine life. Aquatic organisms are sensitive to $\mathrm{pH}$ changes and biological treatment requires $\mathrm{pH}$ control or monitoring. The toxicity of heavy metals also gets enhanced at particular $\mathrm{pH}$. Thus, $\mathrm{pH}$ is having primary importance in deciding the quality of waste water effluents [28].

Suspended solid (SS): Suspended Solid level of untreated paint effluent ranges from $6912.5 \mathrm{mg} / 1$ to $22528 \mathrm{mg} / \mathrm{l}$ this indicating that the values of SS was higher than the permissible limit $(100 \mathrm{mg} / \mathrm{l})$ prescribed by [29] which may be due to presence of large amounts of salts in the effluent. High suspended concentration can block light from reaching submerged vegetation and it causes less oxygen to be released in to the river. It also causes an increase in surface water temperature absorb heat from sun light, this can cause dissolved oxygen level to fall.

Determination of Phosphorus (PO-24): It is noted that all measured value of reactive phosphate of the paint industries were above the standard limit of $5 \mathrm{mg} / \mathrm{l}$ set by WHO. This may cause an over growth of plants and algae, as the plants and algae die, they become organic material in the water. The enormous decay of this plant matter in turn lowers the oxygen level.

6.3. Determination of biological oxygen demand: BOD levels of untreated paint effluent have a minimum value of $47 \mathrm{mg} / \mathrm{l}$ and maximum value of $600 \mathrm{mg} / \mathrm{l}$ which were higher than the permissible limit $(50 \mathrm{mg} / \mathrm{l})$. Increased concentrations of dissolved organic carbon can create problems in the production of safe drinking water if chlorination is used, as disinfection byproducts, such as trihalomethanes and other compounds toxic to humans, may be produced. Increased oxygen consumption poses a potential threat to a variety of aquatic organisms, including fish. It is, therefore, important to monitor organic pollution to identify areas posing a threat to health, to identify sources of contamination, to ensure adequate treatment, and provide information for decision making to enhance water sustainability.

Determination of Chemical Oxygen Demand: COD of untreated paint effluent ranges between $425 \mathrm{mg} / \mathrm{l}$ and 7662.5 $\mathrm{mg} / \mathrm{l}$ and the values of the COD of untreated sample are beyond the permissible limit $(250 \mathrm{mg} / \mathrm{l})$ of [29]. This may be due to the presence of large amount of toxic substances present in the effluent. This implies an access of organic matter enters the waters; the number of decomposers was increase. These decomposers grow rapidly and use a great deal of Oxygen during their growth this leads to depletion of oxygen can kill aquatic organisms. As the aquatic organisms die, they are broken down by decomposers which lead to further depilation of the oxygen level.

Determination of Chromium (Cr): $\mathrm{Cr}$ content in waste water samples was found to be minimum of $1.5 \mathrm{mg} / \mathrm{L}$ in effluent sample collected from Cadisco paint industry and maximum of $9.32 \mathrm{mg} / \mathrm{L}$ from Nifas Silk paint industry (Figure 3), which was very much higher than the permissible limit of $0.05 \mathrm{mg} / \mathrm{L}$ set by WHO. The experimental data indicates that paint manufacturing industries are the major source for release of toxic $\mathrm{Cr}$ metal 
in surrounding aquatic environment. Acute toxicity of $\mathrm{Cr}$ to invertebrates is highly variable, depending upon species. For invertebrates and fishes, its toxicity is not much acute. $\mathrm{Cr}$ is generally more toxic at higher temperatures and its compounds are known to cause cancer in humans. The toxic effect of $\mathrm{Cr}$ on plants indicate that the roots remain small and the leaves narrow, exhibit reddish brown discoloration with small necrotic blotches.

Determination of cadmium: $\mathrm{Cd}$ is contributed to the surface water through paints, pigments, glass enamel, and deterioration of the galvanized pipes etc. Cd content in water samples were found to be minimum of $1.58 \mathrm{mg} / \mathrm{L}$ and maximum $69.22 \mathrm{mg} / \mathrm{L}$ in the effluent samples collected from Cadisco and Rainbow paint industries respectively. The second largest contribution $(16.82 \mathrm{mg} / \mathrm{L})$ of Cd metal was due to the effluent from Bright paint manufacturing industry (Figure 3 ). The experimental values indicate that Rainbow and Bright paint manufacturing industries are the major source for release of toxic $\mathrm{Cd}$ in the surrounding water bodies. The values obtained were found to be extremely higher than the permissible limit of $0.01 \mathrm{mg} / \mathrm{L}$ set by WHO and also according to USPH standards. There are a few recorded instances of $\mathrm{Cd}$ poisoning in human beings following consumption of contaminated fishes. It is less toxic to plants than $\mathrm{Cu}$, similar in toxicity to $\mathrm{Pb}$ and $\mathrm{Cr}$. It is equally toxic to invertebrates and fishes.

Determination of copper: From the results it appears that the $\mathrm{Cu}$ content was minimum of $2.09 \mathrm{mg} / \mathrm{L}$ in the effluent samples collected from Cadisco paint industry, while maximum $\mathrm{Cu}$ content of $189.16 \mathrm{mg} / \mathrm{L}$ was found in effluents from Bright paint manufacturing industry (Figure 3). It was observed that rainbow paint industry was the second largest contributors of toxic $\mathrm{Cu}$ in the aquatic environment showing respectively $22.47 \mathrm{mg} / \mathrm{L}$ of $\mathrm{Cu}$ in their effluent samples. The observed concentration of $\mathrm{Cu}$ in the effluent samples collected from different paint industries were above the permissible limit of $0.05 \mathrm{mg} / \mathrm{L}$ set by WHO and $1.0 \mathrm{mg} / \mathrm{L}$ as per the USPH standard. It is important here to note that $\mathrm{Cu}$ is highly toxic to most fishes, invertebrates and aquatic plants than any other heavy metal except mercury. It reduces growth and rate of reproduction in plants and animals. The chronic level of $\mathrm{Cu}$ is $0.02-0.2 \mathrm{mg} / \mathrm{L}$.Aquatic plants absorb three times more $\mathrm{Cu}$ than plants on dry lands. Excessive $\mathrm{Cu}$ content can cause damage to roots, by attacking the cell membrane and destroying the normal membrane structure; inhibited root growth and formation of numerous short, brownish secondary roots. $\mathrm{Cu}$ becomes toxic for organisms when the rate of absorption is greater than the rate of excretion, and as $\mathrm{Cu}$ is readily accumulated by plants and animals, it is very important to minimize its level in the waterway.

Determination of lead: Lead is one of the oldest metals known to man and is discharged in the surface water through paints, solders, pipes, building material, gasoline etc. Lead is a well-known metal toxicant and it is gradually being phased out of the materials that human beings regularly use. Atmospheric fallout is usually the most important source of lead in the fresh water. In the present investigation, it was observed that the maximum concentration of $\mathrm{Pb}$ was $53.4 \mathrm{mg} / \mathrm{L}$ in effluent samples collected from rainbow paint manufacturing industry, while second largest contribution of $24.84 \mathrm{mg} / \mathrm{L}$ was found in the effluents of Zemillic paint manufacturing industry (Figure 3).

The minimum concentration $(0.68 \mathrm{mg} / \mathrm{L})$ of $\mathrm{Pb}$ was found in the effluent samples collected from Cadisco paint industry. However in all the cases the concentration of toxic $\mathrm{Pb}$ in effluent samples was found to be extremely above the permissible limit of $<0.05 \mathrm{mg} / \mathrm{L}$ lead in drinking water according to the USPH drinking water standards. Acute toxicity generally appears in aquatic plants at concentration of $0.1-5.0 \mathrm{mg} / \mathrm{L}$. In plants, it initially results in enhanced growth, but from a concentration of 5 ppm onwards, this is counteracted by severe growth retardation, discoloration and morphological abnormalities. There is an adverse influence on photosynthesis, respiration and other metabolic processes. Acute toxicity of $\mathrm{Pb}$ in invertebrates is reported at concentration of 0.1-10 mg/L. Higher levels pose eventual threat to fisheries resources.

Determination of Silver (Ag): In the present study, the maximum concentration of Ag was $28.06 \mathrm{mg} / \mathrm{L}$ in the effluent samples collected from Bright paint industry (Figure 3). It was observed that paint manufacturing industries are the largest contributor of toxic Ag in aquatic environment. The minimum concentration of $\mathrm{Ag}(5.69 \mathrm{mg} / \mathrm{L})$ was found in the effluent sample released from Nifas Silk paint industry. However, it was observed that the concentration of toxic Ag in effluent samples collected from different paint industry ware very much higher than the permissible limit of $0.3 \mathrm{mg} / \mathrm{L}$ set by WHO. The presence of high concentration of Ag may increase the hazard of pathogenic organisms; since most of these organisms need Ag for their growth.

\section{Conclusion}

Around the world as countries are struggling to arrive at an effective regulatory regime to control the discharge of industrial effluents into their ecosystems, the present experimental data indicates high level of pollution along Addis Ababa, Ethiopia. The experimental data suggests a need to implement common objectives, compatible policies and programs for improvement in the paint industrial waste water treatment methods. It also suggests a need of consistent, internationally recognized data driven strategy to assess the quality of waste water effluent and generation of international standards for evaluation of contamination levels. The existing situation if mishandled can cause irreparable eco-logical harm in the long -term well masked by short term economic prosperity. From the results of the Physico-chemical analysis and heavy metal contents are 
evident that all the analyzed parameters showed compliance with EPA and WHO standard limits. The results of the Atomic Absorption Spectroscopy indicate that different kinds of metals are contained in the waste water samples; hence contamination of the ecosystem is eminent.

\section{References}

1. MA Aboulhassan, S Souabi, A Yaacoubi, M Baudu (2014) Treatment of Paint Manufacturing Waste water. International Journal of Science, Environment and Technology 3(5): 1747-1758.

2. Debnath NC, Shilpa A Vaidya (2006) Application of X-ray diffraction technique for characterization of pigments and control of paints quality. Progress Organic Coatings 56: 159-168.

3. Bahadir K Korbahti, Abdurrahman Tanyolac (2009) Electrochemical treatment of simulated industrial paint wastewater in a continuous tubular reactor. Chemical Engineering J 148: 444-451.

4. BK Dey, Mohd Ali Hashim, S Hasan, Bhaskar Sen Gupta (2004) Microfiltration of water-based paint effluents. Advances in Environmental Research 8: 455-466.

5. Aboulhassan MA, Souabi S, Yaacoubi A, Baudu M (2006) Improvement of paint effluents coagulation using natural and synthetic coagulant aids. J Hazardous Materials 138(1): 40-45.

6. A Aghor (2007) Chemicals make Thane creek the worst polluted water body. Daily DNA, Mumbai, India.

7. Dhanesh Patil (2009) A lot's fishy about our creek and lake fish. Daily Times of India. March 22, Mumbai, India.

8. Pravin U, Asmita G, Ram S Lokhande (2011) Water pollution by discharge effluents from Gove Industrial Area of Maharashtra, India: Dispersion of heavy metals and their Toxic effects. International Journal of Global Environmental Issues 11(1): 28-36.

9. Pravin Uttam Singare (2011) Heavy metal-in and around the lakes, Pollution due to toxic heavy metals at the Jail Talav and Kalwa Lakes of Thane City. EurekAlert-Atmospheric Science, Mumbai, India.

10. Pravin Uttam Singare (2011) Thane lakes high on metal content: Study. Daily Times of India, Mumbai, India.

11. Adams WJ, Kimerle RA, Barnett JW (1992) Sediment quality: and aquatic life assessment. Environ. Sci.Technol 26(10): 1864-1875.

12. Maher W, Batley GE, Lawrence I (1999) Assessing the health of sediment ecosystems: use of chemicalmeasurements. Freshwater Biology 41(2): 361-372.

13. Kennicutt MC, Wade TL, Presley BJ, Requejo AG, Brooks JM, et al. (1994) Sediment contaminants in Casco Bay, Maine: Inventories, sources and potential for biological impact. Environmental Science and Technology 28(1): $1-15$

14. Pravin U Singare, Ram S Lokhande, Pragati P Pathak (2010) Soil Pollution along Kalwa Bridge at Thane Creek of Maharashtra, India. Journal of Environmental Protection 1(1): 121-128.
15. Johansson J, Rasmussen L (1977) Retrospective study (1944-1976) of heavy metals in the epiphyte Pterogoniumgracile collected from one phorophyte. Bryologist 80(3): 625-629.

16. W Salomons, U Forstner (1984) Metals in the Hydrocycle. SpringerVerlag, New York, USA.

17. Byeong Gweon Lee, Sarah B Griscom, Jung Suk Lee, Heesun J Choi, Chul Hwan Koh (2000) Influence of dietary uptake and reactive sulfides on metal bioavailability from aquatic sediments. Science, 287(5451): 282-284.

18. Donald P Weston, Keith A Maruya (2002) Predicting bioavailability and bioaccumulation with in vitro digestive fluid extraction. Environmental Toxicology and Chemistry 21(5): 962-967.

19. American Public Health Association, APHA (1998) Standard Methods for the examination of water and wastewater, $\left(20^{\text {th }}\right.$ edn $)$, Washington DC, USA.

20. Ram S Lokhande, Pravin U Singare, Deepali S Pimple (2011) Study on Physico-Chemical Parameters of Waste Water Effluents from Taloja Industrial Area of Mumbai, India. International Journal of Ecosystem 1(1): $1-9$.

21. EPA. 2003. Provisional standards for industrial pollution control in Ethiopia. Ecologically Sustainable Industrial Development (ESID) Project US/ETH/99/068/Ethiopia, EPA/UNIDO, Addis Ababa, Ethiopia.

22. USEPA (1990) Guides to Pollution Prevention: The Paint Manufacturing Industry.

23. LS Clesceri, Standard methods for the examination of Water and waste water', In E Arnold, Greenbergy, AD Eaton (Eds.): Collection and Preservation of Samples and Metals, Washington DC, USA.

24. A Paar (1998) Microwave Sample Preparation System-Instruction Handbook, Anton Paar GmbH, Austria: 128.

25. A.K. De (2002) Environmental Chemistry. New Age International (P) Ltd, (4 ${ }^{\text {th }}$ edn): 232-272, New Delhi, India.

26.JW Moore, S Ramamoorthy (1984) Heavy Metals in NaturalWaters: Applied Monitoring and Impact Assessment. Springer-Verlag, New York, USA, pp. 28-246.

27. Ember L (1975) The Spectra of Cancer. Environmental Science and Technology 9(13): 1116-1121.

28. NS Tiwana, N Jerath, G Singh, M Ravens (2005) Heavy metal pollution in Punjab rivers, in Newsletter Environmental Information System (ENVIS). Punjab State Council for Science and Technology, India 3(1): 3-7.

29. (2001) Centre for Ecological Sciences, II Sc Environmental Hand Book: Documentation on Monitoring and Evaluating Environmental Impacts. Compendium of Environmental Standards, Indian Institute of Science, Bangalore, India, vol.3. 
This work is licensed under Creative Commons Attribution 4.0 License DOI :10.19080/JFSCI.2017.05.555685
Your next submission with Juniper Publishers will reach you the below assets

- Quality Editorial service

- Swift Peer Review

- Reprints availability

- E-prints Service

- Manuscript Podcast for convenient understanding

- Global attainment for your research

- Manuscript accessibility in different formats ( Pdf, E-pub, Full Text, Audio)

- Unceasing customer service

Track the below URL for one-step submission https://juniperpublishers.com/online-submission.php 